\title{
Supply Chain Management of Biomass for Energy Generation: A Critical Analysis of Main Trends
}

\author{
Luís Oscar Silva Martins ${ }^{1,2}$, Roberto Antônio Fortuna Carneiro ${ }^{2}$, Ednildo Andrade Torres ${ }^{2}$, \\ Marcelo Santana Silva ${ }^{2,3}$, Eleni Iacovidou ${ }^{4}$, Fábio Matos Fernades ${ }^{2}$ \& Gaudêncio Mendonça Freires ${ }^{2}$ \\ ${ }^{1}$ Federal University of Recôncavo of Bahia, Feira de Santana, Brazil \\ ${ }^{2}$ Federal University of Bahia, Salvador, Brazil \\ ${ }^{3}$ Federal Institute of Bahia, Santo Amaro, Brazil \\ ${ }^{4}$ Brunel University London, London, United Kingdom \\ Correspondence: Luís Oscar Silva Martins, Interdisciplinary Center for Energy and Environment, Federal \\ University of Bahia, Barão de Jeremoabo St. Ondina Campus, 40170-115, Salvador, Bahia, Brazil. Tel: \\ 55-759-9981-3170. E-mail: luisoscar@ufrb.edu.br
}

Received: February 12, 2019

Accepted: April 9, $2019 \quad$ Online Published: August 15, 2019

doi:10.5539/jas.v11n13p253

URL: https://doi.org/10.5539/jas.v11n13p253

\begin{abstract}
The increasing need of decarbonising energy intensive processes has risen the demand for biomass. Biomass production, distribution and use for energy generation involve several supply chain systems of which understanding requires a comprehensive analysis of the biomass supply chain management. The present article maps the volume and diversity of research carried out in the production and management of biomass supply chains for energy generation. It critically evaluates how well studies have captured multidimensional issues pertaining the supply chain management of biomass used for energy production and identifies future research trends in this field. The VOSviewer (Center for Science and Technology Studies, Leiden University, Leiden, The Netherlands) and SciMat (University of Granada, Spain) tools are employed for the construction of scientific maps that demonstrate the evolution of research in the biomass supply chain management area for energy production. The results revealed that research on the biomass supply chain for power generation is booming, especially in the United States, England and Italy. However, in developing nations such as Brazil, India and China, studies are still at an infant stage. There is a rising concern about the emerging new trends related to biomass supply chain management for energy generation, especially if clean energy aims to be a prominent place in the global energy matrix.
\end{abstract}

Keywords: supply chain management, energy, biomass, bibliometric research

\section{Introduction}

Biomass is considered the most prevalent replacement of fossil fuels and is widely used in global energy production (Iacovidou, Hahladakis, Deans, Velis, \& Purnell, 2017). In the power generation sector, biomass contributes to $9.7 \%$ of the total primary energy generation (Internacional Energy Agency [IEA], 2017); larger than the contribution of traditional and technically well-developed sources, e.g. nuclear (4.9\%), hydropower $(2.5 \%)$, wind (3.4\%) and solar (1\%). This is due to the fact that bioenergy, i.e. the energy produced from biomass, is considered a readily available renewable form of energy. Renewable energy reduces greenhouse gases (GHG) emission, while it promotes diversification of energy sources, energy security, regional development and employment and a source of income in rural areas (Benedek, Tihamer-Tibor, \& Bartók, 2018).

Air pollution caused mostly by the fossil fuels combustion can cause premature deaths, respiratory diseases and other human health impacts (World Health Organization [WHO], 2018). In addition, air pollution can cause land degradation, water pollution and global warming (Perera, 2017; Union of Concerned Scientists [UCSUSA], 2016), all of which are associated with high mitigation costs. Although bioenergy can address some of these challenges, it can also present a number of implications due to biomass planting, harvesting, distribution and use. These implications must be taken into account when assessing the sustainability of this option, especially because of the population growth, economic uncertainties, natural disasters, political and organizational aspects that will affect the competition between biomass demand for food, energy and bioplastics in the future. 
This indicates that a transition to a sustainable energy system requires the design of a reliable and sustainable supply chain (Salimi \& Vandani, 2018). An interest in supply chain management (SCM) has grown significantly over the past decades. Although there is currently an extensive body of literature in the SCM of a variety of resources, there are limited studies on the SCM of biomass used for energy generation, known as biomass-to-energy SCM. This could be attributed to business competitiveness (Olsson, Eriksson, Sjostrom, \& Arenud, 2016; Van Dam, de Klerk-Engels, Struik, \& Rabbinge, 2005; Vyhmeister, Ruiz-Mercado, Torres, \& Posada, 2018), as well as to the increasing complexity associated with biomass supply systems and their logistics. This is due to the fact that biomass for energy generation can be obtained from a variety of sources, such as forestry, agricultural and industrial residues (e.g., firewood, charcoal, bioethanol, biodiesel, among others) (Iakovou, Karagiannidis, Vlachos, Toka, \& Malamakis, 2010). It can also be acquired from specifically grown energy crops (e.g., miscanthus, switchgrass), as well as biosolids, animal residues and livestock processing waste, and the organic fraction of municipal solid waste (e.g. food and green waste) (Iakovou et al., 2010).

This diversity of biomass sources implies two key challenges associated with biomass-to-energy SCM: i) the geographic dispersion of biomass feedstock availability and supply logistics; and ii) the economic viability of biomass utilisation due to lower conversion efficiencies (i.e., lower energy density per unit mass) compared to fossil fuels. These challenges and their interaction in the biomass-to-energy supply chain need to be well understood to make bioenergy a flexible and adaptable solution to local and interregional contexts (Iakovou et al., 2010). It also has to be resilient to constraints related to existing infrastructure, geographic dispersion of collection areas, the technical-economic environment and competition between sectors (food-energy-materials) and consumers (Iakovou et al., 2010).

In this context, the aim of this article is to map the quantity, quality and thematic diversity of studies on the biomass-to-energy SCM that were carried out over the last two decades. This is achieved by bibliometric methods and by the application of VOSviewer and SciMat tools. In addition, an analysis of period ranges of publications using the Web of Science database is illustrated to establish the quantitative and main results of the supply chain research in the field of bioenergy, given the observed development of this area in recent years.

\section{The Importance of SCM in Biomass-to-Energy Systems}

The use of biomass for the bioenergy production is already practiced in areas where biomass residues are produced, such as in forests or in areas for sugar cane cultivation and crops. In order to obtain the critical mass of biomass residues needed for sufficient energy production, multiple suppliers are often involved in the biomass residues supply chain. This supply chain, also known as waste biomass supply chain (WBSC), is composed of four main steps, including: (i) collection of biomass (from one or more sites) and pretreatment; (ii) storage (at one or more intermediate sites); (iii) transport (single or multiple levels); and (iv) energy conversion, as shown in Figure 1 (Iakovou et al., 2010).

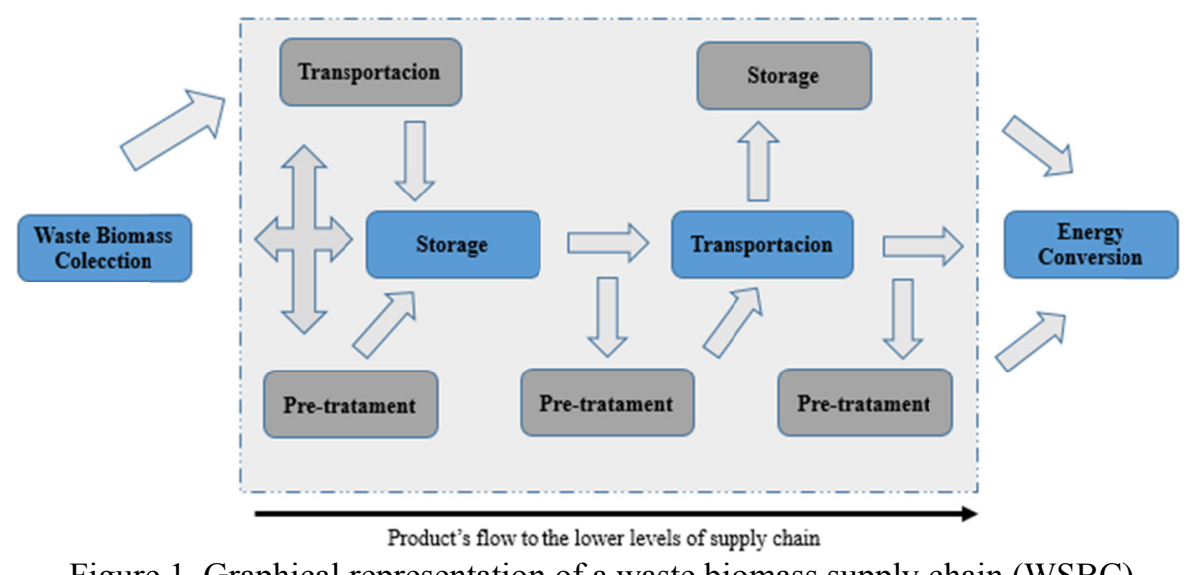

Figure 1. Graphical representation of a waste biomass supply chain (WSBC)

Note. Adapted from Iakovou et al. (2010, p. 1861).

According to Handfield, Soufre, and Walton (2005), WBSC management is the integration of all activities involved in a biomass-to-energy system presented in Figure 1. This includes extraction through to utilization of biomass for energy production, which can support the development of an improved supply-demand relationship, 
as well as the generation of associated information flow. The latter can be extremely useful in achieving a sustainable competitive advantage. Hassini, Surti, and Searcy (2012), who suggested there are six strategically important factors for the successful performance of a supply chain, also support this. These are namely transportation, inventory, facilities, information, prices and supply. Prior to the consideration of these factors in the analysis of the biomass-to-energy supply chain, it is first necessary to understand all the competitive strategy of the stakeholders and how it fits with operational strategy.

That means biomass suppliers and end-users should strive to meet multiples, possibly conflicting, objectives. Also, they have to deal with several different decision makers. Concurrently, they must also demonstrate their competence in assessing the environmental impacts of their operations, as well as the social and economic positive and negative impacts related to these. They must also be prepared to account for any potentially external factors that can put pressure on them, especially for improving the sustainability of their operations. The complete range of all factors that need to be considered in promoting a sustainable supply chain management (SSCM) is shown in Figure 2.

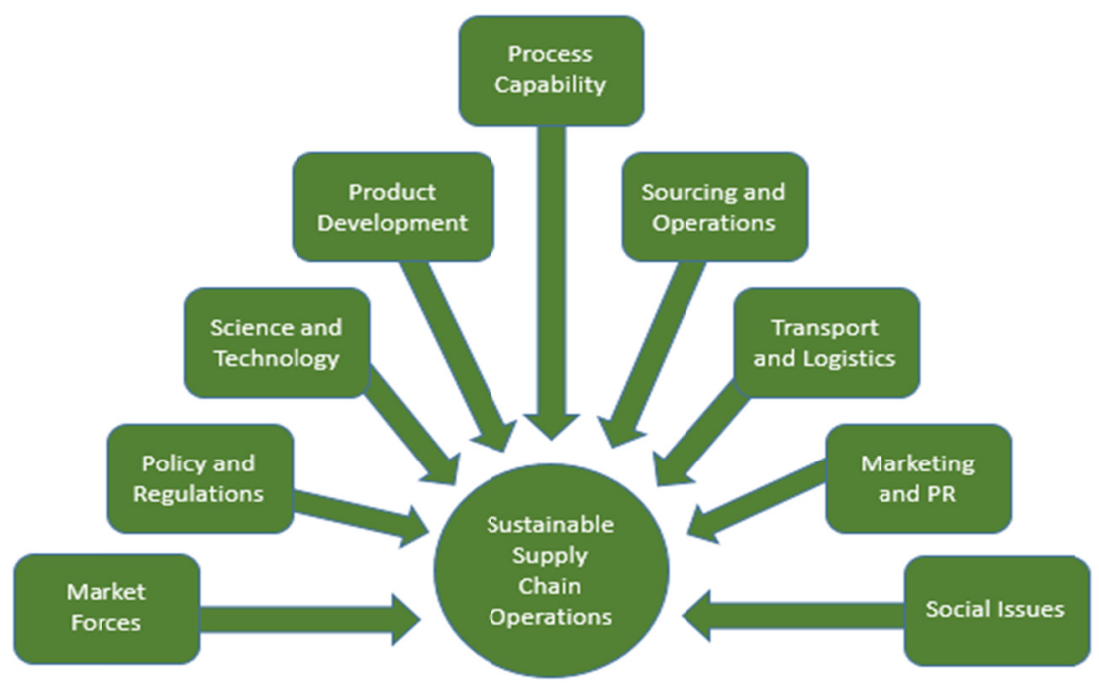

Figure 2. Key factors in supporting a sustainable supply chain operation (Hassini et al., 2012, p. 75)

Improving the knowledge of how to manage the different components of the biomass-to-energy supply chain can aid the use of a variety of primary resources for the bioenergy production. Some of these may have not been traditionally used, such as rice husk, coconut shell or cashew nutshell, for example. The dispersed geographic distribution of biomass was met with widespread interest from the scientific community that sought to identify the amounts of biomass available in a region prior to the selection of the ideal resources for enacting a biomass-to-energy system (Skoulou \& Zabaniotou, 2007).

This is reported in the studies of Ahmed and Sarkar (2018), Jeong and Ramírez-Gómes (2018), S. Kim, S. Kim, and Kiniry (2018) and Svanberg, Finnsgard, Floden, and Lundgren (2018), where the location and geographical distribution of biomass and biorefinery facilities was studied. Specifically, Kim et al. (2018) tried to identify the best location of biorefineries, by considering a stable supply of biomass feedstock and low transportation costs. Ahmed and Sarkar (2018), and Svanberg et al. (2018) also tried to do the same but for facilities that use animal manure, e.g. horse manure, and agricultural crop residues, respectively, as feedstocks for biofuel production. All studies concluded that the supply chain of biomass feedstock can be affected by the geographical distribution of its sources and their distance from the biorefineries. Also, these studies demonstrated that the logistics associated with biomass pretreatment, storage and transportation have to be optimised. To optimise logistics, Gebresenbet, Bosona, Olsson and García-Galindo (2018) proposed the development of a system that improves the performance of the biomass-to-energy SCM system by improving the traceability of the product in the supply chain. This has led to a reduction in losses, to a greater coordination of resources use and biomass feedstock quality, to a better commercialization opportunity and to a reduction of logistic costs.

In the study of Salimi and Vandani (2018), there were addicional aspects that were reported that may affect the biomass-to-energy SCM system sustainability. These authors developed a mathematical model to consider the 
failures in the connection links between the biomass feedstock sources and biorefineries due to spatial distribution and disaster impacts. They suggested that by increasing the reliability and improvement of the connections between the two facilities, supply chain costs can be considerably reduced. Jeong and Ramírez-Gómes (2018), who also supported this finding, applied a combined Multi-Criteria Decision Analysis (MCDA) and Fuzzy-MAcking Assessment Laboratory (F-DEMATEL) technique to identify suitable and favorable sites for biomass feedstock production and utilisation, using environmental, geophysical and socioeconomic criteria. The results of their analysis suggested that the ideal sites for biorefineries are near forests and in areas with low transport costs. The criteria that determined the sustainability of that particular biomass-to-energy supply chain management system were the plant cover, agricultural area, transportation cost and potential demand. This methodology can be used to verify suitable sites for biomass plants and decision-making in the private sector and at various levels of the government.

Regarding the safety of the residual biomass supply, Vacchiano, Berreti, Motta, and Mondino (2018) studied how to quantify the biomass required to design the location and size of the plants for energy and heat generation. The authors developed their research using an algorithm to measure available forest biomass using publicly accessible Landsat satellite images, regional forest inventory data, an artificial neural network (RNA) classifier using remote sensing information, the Improved Vegetation Index (EVI) and topography data. This combination resulted in a biomass forest map that reported the biomass available for bioenergy production from crop residues based on density of species-specific wood, biomass expansion factors, available volumes, forest accessibility and topography.

Corcelli, Fiorentino, Vehmas, and Ulgiati (2018) used Life Cycle Analysis (LCA) as a research tool to study the use of energy generated in-situ from black liquor and residual biomass to support the demands of integrated pulp and paper mills and to reduce environmental burdens. Particularly, the partial generation of electricity and heat, by using waste within the system, leads to a remarkable reduction of impacts in all the categories investigated.

Regarding the production process, that is another important area for the efficient supply chain management, Vyhmeister et al. (2018) developed a study to analyse the challenge of selecting optimal technologies, especially when considering many available alternatives. These authors consider that selecting optimal production paths requires a shift from traditional material management practices to more sustainable practices. A case study was developed in which there were four target areas (efficiency, energy, economy and environment) evaluated by 21 pre-selected indicators as part of a multiobjective optimization problem of a biofuel production network consisting of four main elements: (1) raw materials management; (2) conversion technologies; (3) co-products modernization and (4) auxiliary sections for in-situ production of raw materials and utilities. The evaluation allowed identifying optimal networks, specific target areas with potential improvements and processing steps with great influence on the entire network performance.

In turn, Carleton and Backer (2018) argue that integrating the different interests of decision makers involved in a supply chain in an efficient and sustainable manner requires well-structured governance. It was researched the existing barriers to the development of bioenergy from the perspective of supply chain actors. The conducted interviews demonstrated the need to create subsidies, integrate bioenergy production with bio-based markets, correct poor coordination and lack of greater shared responsibility between state agencies, industry associations and non-profit organizations, resulting in a fragmented policy system. The authors proposed a set of measures to correct these points.

This review has demonstrated that the use of biomass and its residues to produce bioenergy require both a more efficient integration of the various links that make up a supply chain and a better improvement of each of these particular links. What happens is that the development of supply chain management is based on greater studies that seek innovation, competitiveness and greater environmental sustainability.

In this sense, to verify how the research is being developed and directed in this field, a bibliometric survey was held. This survey mapped the volume and diversity of publications carried out in the scope of Supply Chain Management in bioenergy to construct scientific maps from studies considered relevant. The aim of this was to demonstrate how scientific research is evolving in this area.

\section{Methodology}

Bibliometric method or analysis has emerged in the early twentieth century as a quantitative tool for evaluating the contribution of present studies in a research field and predicting their future research potential. That means bibliometric studies aim to demonstrate the direction of science in a certain field of knowledge (Gautam, 2017). Currently, this type of analysis is considered an established process of research evaluation, especially within the scientific and applied fields (Ellegaard \& Wallin, 2015). 
In this way, the present article is characterized as a retrospective and employs a bibliometric analysis of secondary data. This type of analysis generates relevant information for researchers who evaluate the evolution of scientific activity (Montero-Diaz, Cobo, Gutiérrez-Salcedo, Segado-Boj, \& Herrera-Viedma, 2018) and that examinate bibliographic material from an objective, quantitative and qualitative perspective that is useful in the organization of information within a specific field (Albort-Morant \& Ribeiro Soriano, 2016).

From a methodological point of view, bibliometric surveys can be understood as a systematic literature reviews through content analysis, where quantitative and qualitative aspects are analysed in their structure (descriptive research) and content criteria. A process model proposed by Mayring (2003) was adapted in our study. This contains the following four steps:

(1) Collection and screening of data;

(2) Descriptive analysis-it involves the processing of data based on, e.g. the number of publications per year, providing the background for later theoretical analyses;

(3) Content analysis-it involves the analysis of data into peripheral, emerging and basic themes;

(4) Material evaluation according to the relevant issues and interpretation of results.

\subsection{Choice of Database}

Thompson Reuters' Clarivate Analytics database, hereinafter referred to as Web of Science, was chosen as the main data source for gathering research outputs on the SCM of biomass-to-energy system. This database was chosen due to its widespread use and comprehensiveness: the tool has more than 50 thousand academic books, 12 thousand periodicals and 160 thousand congress annals. The Web of Science enables a multidisciplinary view of science and integrates all relevant sources for basic, applied research and technological innovation through patents, scientific content web sources, open access journals, conference proceedings and conferences.

The quality and quantity of biomass-to-energy SCM studies were assessed based on studies published within the last couple of decades. The keywords used to search in the database included the terms: "Biomass" and "Energy" and "Supply Chain Management". The field label used was "Topic" (TS) which selects words in the article title, abstract and keywords. The Boolean term "AND" was used to avoid overcollection of studies that might be irrelevant. Only English articles were researched given the innovative nature of this type of document, as well as its greater ease of disclosure due to the adopted language.

After selecting the technical parameters, the database searching was performed. Initially, the selected period was from 1991 to 2018. The year of 1991 was chosen because it was the period in which the indexation of the keywords in the articles occurred (Miguéis, Neves, Silva, Trindade, \& Bernardes, 2013). However, publications that included the predefined characteristics were only found in year 2000. As a result, this year was selected as the starting point of the analysis, with 221 articles.

\subsection{Software Used}

Two tools were used in the analysis: the VOSviewer and the SciMAT. The VOSviewer is a free-access information technology program developed by Waltman and Van Eck (2012) to create, visualize and explore academic and scientific bibliometric maps, called term maps (Van Eck, Waltman, Dekker, \& Van Den Berg, 2010). A term map is a two-dimensional map in which the occurrence frequency of a specific term is defined by the size of the label. For example, the larger the label, the higher the occurrence of the specific term. The distance between two terms can be interpreted as an indication of the relation of these terms based on the number of co-occurrences between them (Castillo-Vergara, Alvarez-Marin, \& Placencio-Hidalgo, 2018). The analysis made in this program considers countries, most cited authors and keywords. The main advantage of this program is it focuses on the graphical representations of the data collected in a map, providing better insights on the purpose, scope and scale of the research conducted. This is particularly useful in viewing large datasets and facilitating interpretation (Cobo, López-Herrera, Herrera-Viedma, \& Herrera, 2011; Dae-Hyun, Cho, Park, \& Hong, 2016). The SciMAT tool developed by the University of Granada SECABA group is an open source software, created to carry out scientific mapping analysis in longitudinal structure. SciMAT allows the construction of scientific maps, as well as a better visualization of evolution within a scientific area (Cobo, López-Herrera, Herrera-Viedma, \& Herrera, 2012). The system offers a diversity of resources that helps the researcher to conduct workflows that aid the mapping of science. The following flows were established for this research: the first one dedicated to the management of the knowledge base and its specificities, such as year and number of publications; the second dedicated to the analysis and mapping of science; and a third stream created to present the results and generated maps. 
Based on the methodology proposed by Mayring (2003), four strategic maps were constructed using SciMAT. The first map incorporates all the research developed, and the remainder represents an analysis by time interval [2000 to 2006], [2007 to 2012] and [2013 to 2018] using the measures of centrality and density. By presenting only three time intervals, trends in publication patterns could be visualized.

Thus, according to the structural divisions proposed by Higuita, Awad, and Cardona (2012), the present study used quantitative indicators to measure the productivity of a researcher, periodical or institution in terms of the number of publications. These indicators aim to measure the frequency with which an article, author or journal is cited in other publications, as well as measure the connectivity between them.

In the SciMAT operating environment, the following configuration was established: i) word as unit of analysis, ii) co-occurrence analysis as tool to build networks, iii) equivalence index as a measure of similarity to normalize networks, iv) simple algorithm used in detection of clusters and v) creation of strategic diagrams subdivided into four quadrants shown in Figure 3 (Cobo et al., 2012).

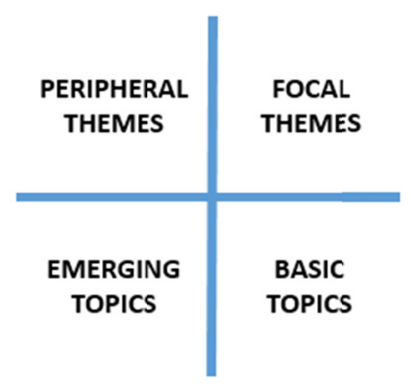

Figure 3. Themes' division by quadrants, according to SciMat algorithm

The focal themes are those that are properly developed and are important in the construction of knowledge in a scientific topic, since they represent a strong centrality and involve high density of research. Peripheral themes correspond to themes internally well developed, but that are isolated from other themes and possess marginal importance in the evolution of academic research. Emerging themes are those that are underdeveloped, usually involving exploratory and discursive research. The basic themes are important subjects for the scientific field, but they are not adequately developed (Castillo-Vergara et al., 2018).

\section{Results and Discussion}

The basic body of the identified literature was composed of 221 articles. The distribution of publications in the survey period from 2000 to 2018 is illustrated in Figure 4. In the first year of analysis (2000), only one article was published on the biomass-to-energy SCM, with numbers of studies on this topic remaining low until 2008. The interest for the biomass-to-energy SCM has began to increase in 2009, consolidating from 2013 onward with an average of 30 publications per year until October 2018. This sudden growth of interest can be attributed to the increasing volatility in fossil fuel prices and the environmental impacts of fossil fuels on the environment and human health, coupled with an ever-increasing global energy demand. These concerns have been intense in the political agendas and in climate debates conventions, as for example the $21^{\text {a }}$ Conference of The Parties (COP 21) held in Paris in December 2015, in which the world was pressured for a global reduction in $\mathrm{CO}_{2}$ emissions. 


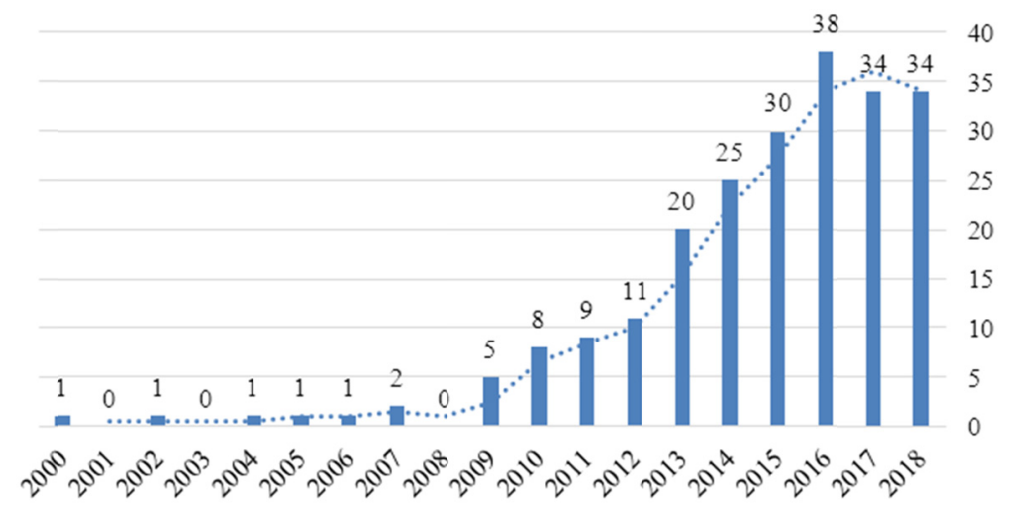

Figure 4. Distribution of publications per year in the period studied

The country with the biggest number of publications on biomass-to energy SCM are the United States (US) with 54 articles, followed by Italy and England with 34 and 24 articles, respectively. US interest is associated with the growing demand for energy and its commitment to reduce energy dependence on fossil fuels. Historically the United States has been placing great effort on maintaining and improving its energy security to remain competitive in the international arena (Steeves \& Ouriques, 2016; Zhang, Yang, Sheng, Li, \& Whang, 2014). This means they are competing for access and control for renewable energy resources as well (Steeves \& Ouriques, 2016; Zhang et al., 2014). In Europe (EU), there was great emphasis on increasing energy generation from biomass to address the rising concerns about climate and energy (Commission of the European Communities, 2008, 2009). A relevant legislation was formulated to oblige EU member states to increase their renewable energy generation (Commission of the European Communities, 2008, 2009). Italy and the United Kingdom (UK) seem to have been the member states that have engaged great efforts in understanding how to diversify their energy supply and increase their bioenergy potential to achieve their targets. Figure 5 shows the amount of citation from studies conducted on the biomass-to-energy SCM topic in different countries. The studies conducted in the United States were the most cited with 1,515 citations in total, followed by the studies conducted in England (696 times in total) and Italy (384).

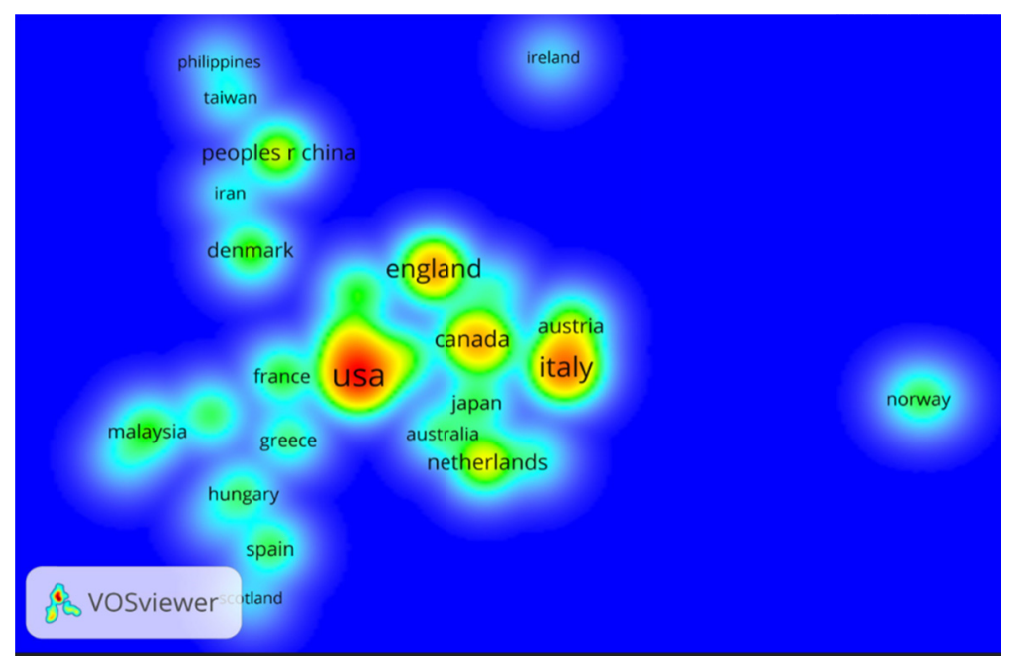

Figure 5. Mapping of the citations by country using the VOSviewer software

Regarding the authorship of studies on biomass-to-energy SCM, the publications are from numerous authors. Table 1 presents the authors with three or more published studies, but the actual number of researchers that published studies on the topic of biomass-to-energy SCM is up to 668. Lam is the researcher with the highest number of publications (7), followed by Balaman, De Meyer and Van Orshoven, with six publications each. 
Table 1. Number of biomass-to-energy SCM publications and the number of times these studies were cited within years 2000-2018

\begin{tabular}{lllll}
\hline Authors & Publications & Citations & h-Index & Avarege \\
\hline Lam HL & 7 & 216 & 5 & 30.86 \\
Balaman SY & 6 & 59 & 4 & 9.83 \\
De Meyer A & 6 & 53 & 4 & 8.83 \\
Van Orshoven J & 6 & 53 & 4 & 8.83 \\
Cattrysse D & 5 & 41 & 3 & 8.20 \\
Bonari E & 4 & 25 & 3 & 6.25 \\
Dragoni F & 4 & 128 & 2 & 42.67 \\
Bezzo F & 3 & 128 & 2 & 42.67 \\
Buyuktahtakin IE & 3 & 40 & 3 & 13.33 \\
Cobuloglu HI & 3 & 40 & 3 & 13.33 \\
Faaij A & 3 & 57 & 3 & 19.00 \\
Garofalo P & 3 & 7 & 2 & 2.33 \\
Junginger M & 3 & 34 & 3 & 11.33 \\
Liu YY & 3 & 5 & 2 & 1.67 \\
Ragaglini G & 3 & 21 & 2 & 7.00 \\
Routa J & 3 & 56 & 3 & 18.67 \\
Selim H & 3 & 49 & 3 & 16.33 \\
Sikanen L & 3 & 32 & 3 & 10.67 \\
Sokhansanj S & 3 & 146 & 2 & 48.67 \\
Sowlati T & 3 & 61 & 2 & 20.33 \\
Stampfer K & 3 & 34 & 3 & 11.33 \\
Tozzini C & 3 & 21 & 2 & 7.00 \\
Vonella AV & 3 & 7 & 2 & 2.33 \\
\hline
\end{tabular}

Also, in Table 1, the Hirsch index or h-index, was included for each author. This was used as an evidence of their work quality, as well as an indication of the prominence of the authors in the field, according to the number of times their research was cited (Schreiber, 2015). The average citation per author is illustrated more clearly in Figure 6.

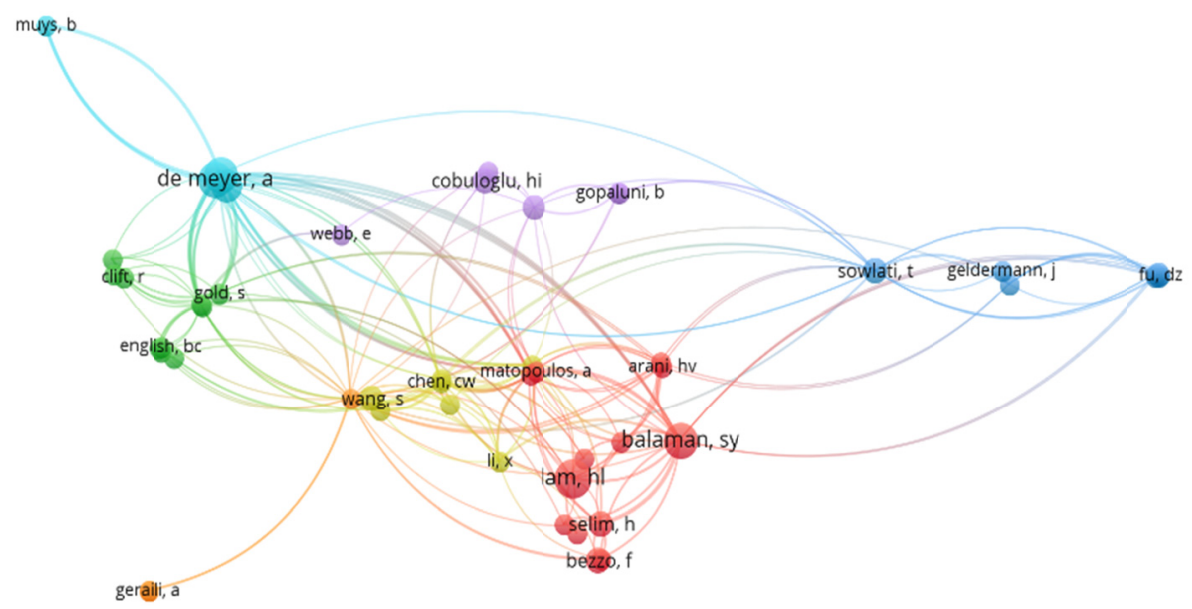

Figure 6. Bibliometric mapping of authors that carried out studies on biomass-to-energy SCM using theVOSviewer software

The focus areas of the 221 studies conducted on biomass-to-energy SCM were on: Energy Fuels (104 articles), Engineering (78) and Environmental Sciences and Ecology (68) (Note 1). The journals that published most studies on the subject were Biomass and Bioenergy (24), Journal of Cleaner Production (21) and Applied Energy (16). These journals are ranked in the Energy Fuels and Engineering web of Science categories and most of the 
agencies that funded and developed the studies are in the United States and England. Table 2 presents the 20 most cited publications on biomass-to-energy SMC out of a total of 221 articles identified on the topic.

Table 2. Most cited publications in the topic of biomass-to-energy SCM

\begin{tabular}{|c|c|c|c|}
\hline Title & Journal & $\begin{array}{l}\text { Year of } \\
\text { Publication }\end{array}$ & $\begin{array}{l}\text { Number of } \\
\text { citations }\end{array}$ \\
\hline Miscanthus: European experience with a novel energy crop & Biomass \& Bioenergy & 2000 & 515 \\
\hline Analyzing the design and management of biomass-to-biorefinery supply chain & $\begin{array}{l}\text { Computers \& Industrial } \\
\text { Engineering }\end{array}$ & 2009 & 189 \\
\hline Supply chain and logistics issues of bio-energy production & Journal of Cleaner Production & 2011 & 160 \\
\hline $\begin{array}{l}\text { Large-scale production, harvest and logistics of switchgrass (Panicum virgatum } \\
\text { L.)-current technology and envisioning a mature technology }\end{array}$ & $\begin{array}{l}\text { Biofuels Bioproducts \& } \\
\text { Biorefining-Biofpr }\end{array}$ & 2009 & 138 \\
\hline $\begin{array}{l}\text { LCA of a biorefinery concept producing bioethanol, bioenergy, and chemicals } \\
\text { from switchgrass }\end{array}$ & $\begin{array}{l}\text { International Journal of } \\
\text { Life Cycle Assessment }\end{array}$ & 2010 & 130 \\
\hline Minimizing carbon footprint of regional biomass supply chains & $\begin{array}{l}\text { Resources Conservation } \\
\text { and Recycling }\end{array}$ & 2010 & 110 \\
\hline Waste biomass-to-energy supply chain management: A critical synthesis & Waste Management & 2010 & 103 \\
\hline $\begin{array}{l}\text { Spatially Explicit Static Model for the Strategic Design of Future Bioethanol } \\
\text { Production Systems. 1. Cost Minimization }\end{array}$ & Energy \& Fuels & 2009 & 103 \\
\hline Developing a sustainability framework for the assessment of bioenergy systems & Energy Policy & 2007 & 98 \\
\hline $\begin{array}{l}\text { Bioethanol supply chain system planning under supply and demand } \\
\text { uncertainties }\end{array}$ & $\begin{array}{l}\text { Transportation Research } \\
\text { Part E-Logistics }\end{array}$ & 2012 & 88 \\
\hline $\begin{array}{l}\text { Modeling of biomass-to-energy supply chain operations: Applications, } \\
\text { challenges and research directions }\end{array}$ & Energy Policy & 2014 & 76 \\
\hline $\begin{array}{l}\text { An integrated optimization model for switchgrass-based bioethanol supply } \\
\text { chain }\end{array}$ & Applied Energy & 2013 & 68 \\
\hline $\begin{array}{l}\text { Two levels decision system for efficient planning and implementation of } \\
\text { bioenergy production }\end{array}$ & $\begin{array}{l}\text { Energy Conversion } \\
\text { and Management }\end{array}$ & 2007 & 58 \\
\hline $\begin{array}{l}\text { A mixed integer non-linear programming model for tactical value chain } \\
\text { optimization of a wood biomass power plant }\end{array}$ & Applied Energy & 2013 & 55 \\
\hline Regional renewable energy and resource planning & Applied Energy & 2011 & 52 \\
\hline $\begin{array}{l}\text { Development of a simulation model of biomass supply chain for biofuel } \\
\text { production }\end{array}$ & Renewable Energy & 2012 & 48 \\
\hline $\begin{array}{l}\text { Criteria and indicators for sustainable forest fuel production and harvesting: } \\
\text { A review of current standards for sustainable forest management }\end{array}$ & Biomass \& Bioenergy & 2011 & 45 \\
\hline Carbon and nitrogen trade-offs in biomass energy production & $\begin{array}{l}\text { Clean Technologies } \\
\text { \& Environmental Policy }\end{array}$ & 2012 & 38 \\
\hline $\begin{array}{l}\text { How certain are greenhouse gas reductions from bioenergy? Life cycle } \\
\text { assessment and uncertainty analysis of wood pellet-to-electricity supply chains } \\
\text { from forest residues }\end{array}$ & Biomass \& Bioenergy & 2015 & 37 \\
\hline $\begin{array}{l}\text { Design of regional and sustainable bio-based networks for electricity generation } \\
\text { using a multi-objective MILP approach }\end{array}$ & Energy & 2012 & 37 \\
\hline
\end{tabular}

The most highly cited article, i.e., "Miscanthus: European experience with a novel energy crop" by Lewandowski, Clifton-Brown, Scurlock, and Huisman (2000), analyses the use of miscanthus for bioenergy generation and current options for its production. This study presents replicable findings in other parts of the world, such as the United States. They concluded miscanthus possessed the technical capacity for heat generation, but limitations related to its high implantation cost and need for irrigation should be taken into account.

The second most highly cited article was from Eksioglu, Acharya, Leightley, and Arora (2009): "Analyzing the design and management of biomass-to-biorefinery supply chain", which discussed the logistical challenges of supplying biomass, especially corn and soybeans, for power generation. The study presented a mathematical model for projecting future aspects pertaining the supply chain management of biomass and its logistic implications in the biorefinery use, contemplating the processes involved in short, medium and long-term decision making. 
The third most cited article, i.e., "Supply chain and logistics issues of bio-energy production" (160 citations) by Gold and Seuring (2011), presented a bibliometric survey on supply chain management and bioenergy production. It highlights the main logistical challenges that cover the interface of bioenergy production and supply chain management.

\subsection{Content Analysis}

The study period used for content analysis was divided into three blocks: i) 2000 to 2006; ii) 2007 to 2012 ; and 2013 until October 2018. During the last two blocks (2007-2018), there was a gradual increase in the number of publications (181 publications), 34 only in the last year of the analysis. This increase was due to the occurrence of climate conferences, especially COP 21, which highlighted the need to replace gradually fossil fuels with cleaner technologies to reduce greenhouse gas emissions. Figure 7 shows the number of published articles analysed for each time period.

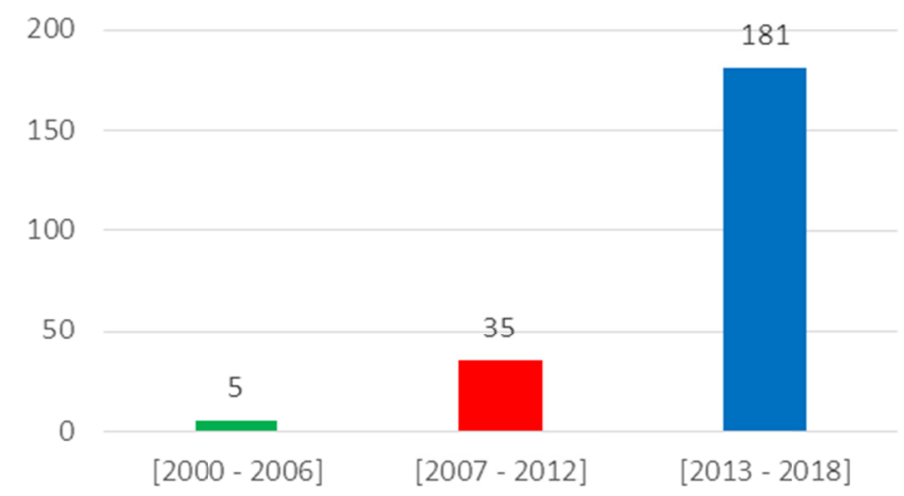

Figure 7. Number of articles per time period (block)

In Cobo's works, which deal with bibliometric research, the maturation level of a theme is related to the number of connections: the more connections there is, more mature the theme is. The diagram presented in Fig. 8 shows that the research theme, 'Management of the supply chain of biomass for energy generation', is in the stage of 'maturation'. The theme is broad and has connections to a diverse range of topics such as renewable energy, land and water use, economy and conversion technologies.

The most used themes were 'supply chain', 'biomass', 'economy' and 'systems', as illustrated by the size of the digraph spheres. Figure 8 indicates the direction of the topic discussed in this research, which can be proved by the separate analysis of the three periods defined in the methodological section, i.e., 2000 to 2006; 2007 to 2012; and 2013 to 2018. Peripheral themes such as 'emissions', 'greenhouse gases' and 'harvest' can also be observed, as well as themes that need better development, such as 'markets'. 


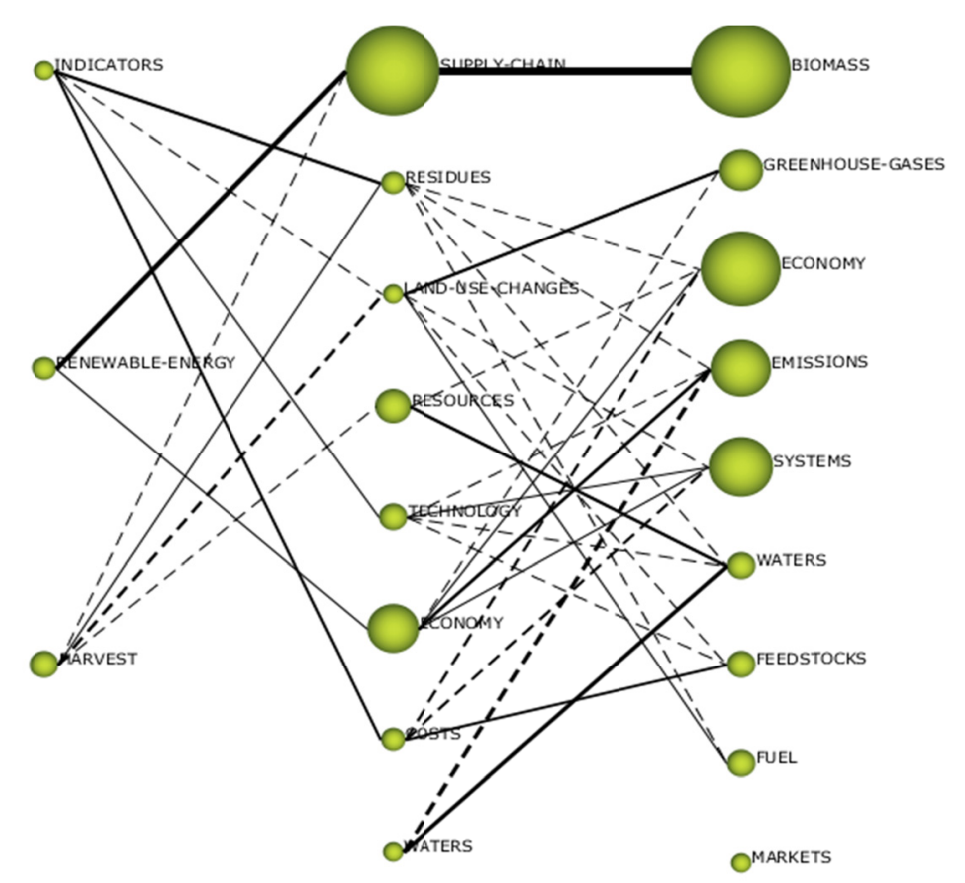

Figure 8. General strategic theme map created using SciMat

In the first period (i.e., 2000 to 2006), illustrated in Figure 9, the most relevant themes were the 'indicators' and 'renewable energy' in studies 1 and 2, respectively, whereas 'harvest' was an emerging theme that appeared in three studies. This can be potentially attributed to the fact that bioenergy was still in its infancy, gaining more traction. Nonetheless, the small number of studies published in this period on the biomass-to-energy SCM research topic does not allow any valid conclusions to be made. The centrality of the terms is related to the relance: 'Indicators' are related to Soil, Grasses, Technology and Costs; 'Renewable-Energy' interconnects to Corn, Energy, Economy and Supply-Chain; 'Harvest' is associated with Biomass, Forest Management, Biorefinery and Fuel. Table 3 shows the result for each topic and the thematic diagram (Figure 9) accent the high index h on supply chain related topics in this period.

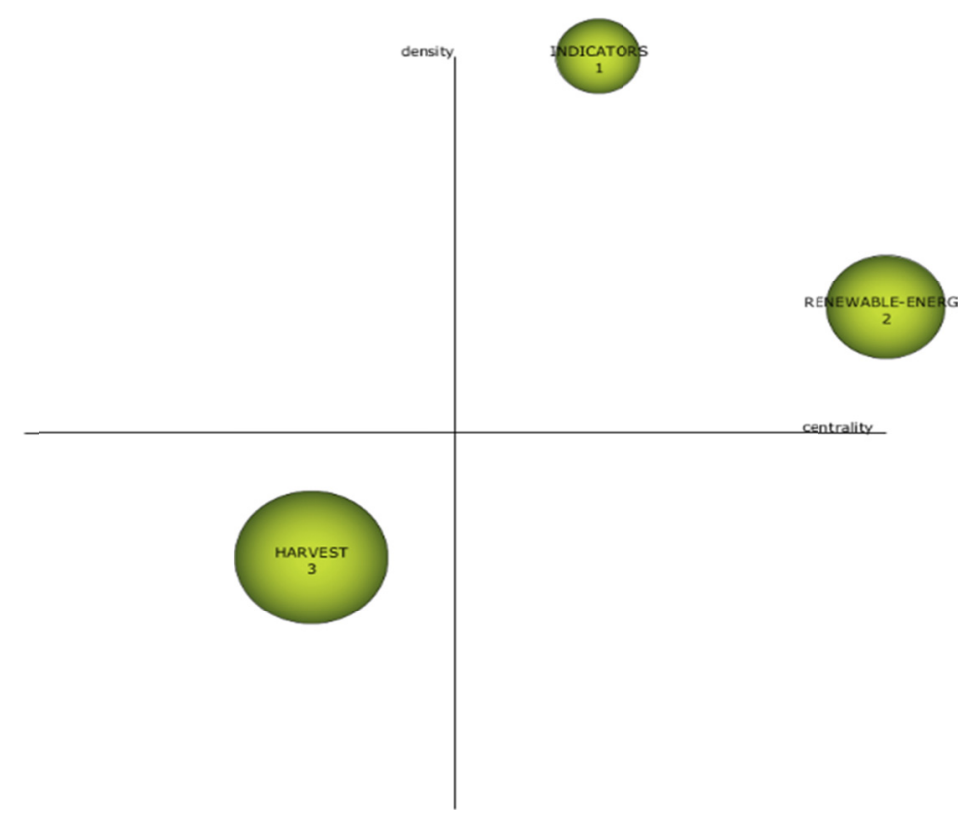

Figure 9. Strategic theme map (2000-2006) constructed using SciMat 
Table 3. Topics of the strategic map 2000 to 2006

\begin{tabular}{lllll}
\hline Topics & Documents & h-index & Centrality & Density \\
\hline Indicators & 1 & 1 & 189.17 & 200 \\
Renewable-Energy & 2 & 2 & 200.83 & 110 \\
Harvest & 3 & 3 & 77.30 & 64 \\
\hline
\end{tabular}

In the second period (i.e., 2007 to 2012) the interest on biomass-to-energy SCM research increased substantially, with themes such as 'supply chain', 'land use change', and 'resources' gaining popularity. Supply chain is strongly linked with 'energy', 'biomass', 'renewable energy', and 'mathematical modeling', which are in turn interconnected. The peripheral themes, located in the upper left quadrant, were developed internally, but were isolated from themes such as 'residues' and 'technology', which were partly classified as emerging themes. Residues are linked to 'harvest', 'indicators', 'soil' and 'bioeconomy'. Table 4 shows the result for each topic and the thematic diagram (Figure 10) highlighting the high index h on Supply-Chain related topics.

Table 4. Topics of the strategic map (2007 to 2012)

\begin{tabular}{lllll}
\hline Topics & Documents & h-index & Centrality & Density \\
\hline Supply Chain & 33 & 20 & 120.30 & 69 \\
Residues & 22 & 2 & 43.54 & 73,75 \\
Land use Changes & 1 & 1 & 58.51 & 46,4 \\
Resources & 5 & 5 & 77.20 & 38,93 \\
Technology & 3 & 3 & 55.06 & 30 \\
Economy & 9 & 9 & 62.76 & 23,42 \\
Costs & 2 & 2 & 56.30 & 2,18 \\
Waters & 1 & 1 & 7.09 & 12,5 \\
\hline
\end{tabular}

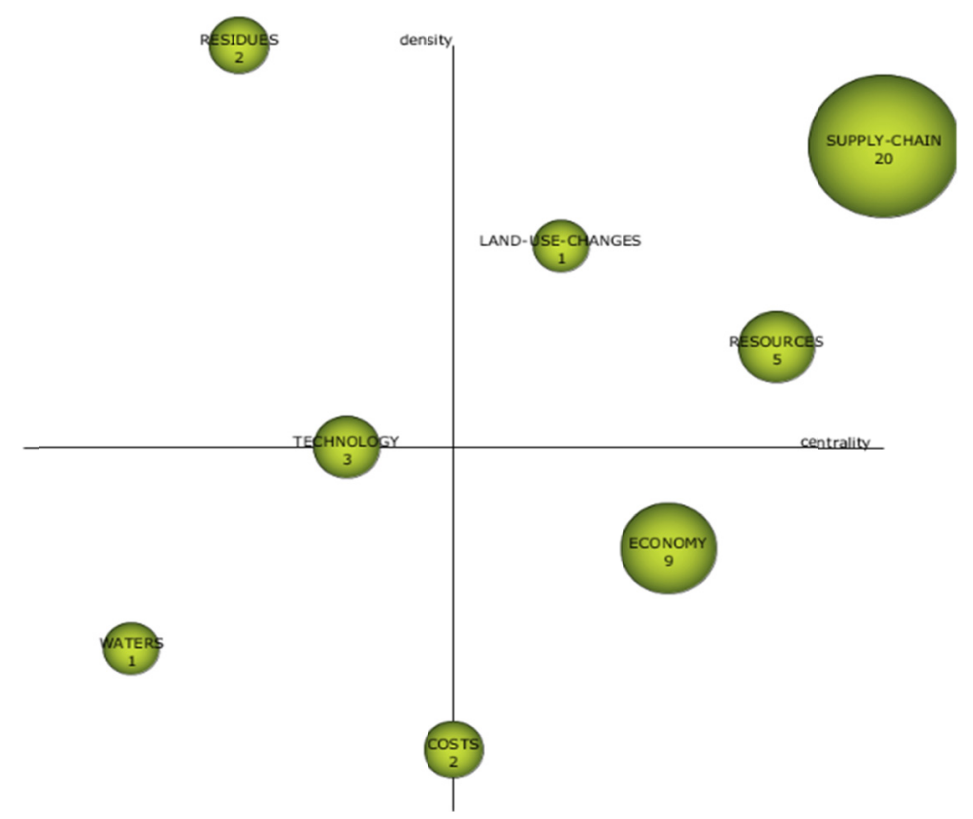

Figure 10. Strategic theme map (2007-2012) constructed using SciMat

The last period interval, i.e., 2013 to 2018 (October 2018), presents a total of nine themes, as shown in Figure 11 and detailed results for each theme in Table 5. There are four focal themes with "Biomass" and "Economy" with the highest index h. There are two focal themes, "Greenhouse-gases" and "Emissions", which tend to combine and become just one item. Emerging topics such as "Feedstocks", "Fuel" and "Waters" are interrelated and influence the issue of energy generation from biomass, especially agricultural inputs and wastes. They also impact in the supply chain of the segment. 


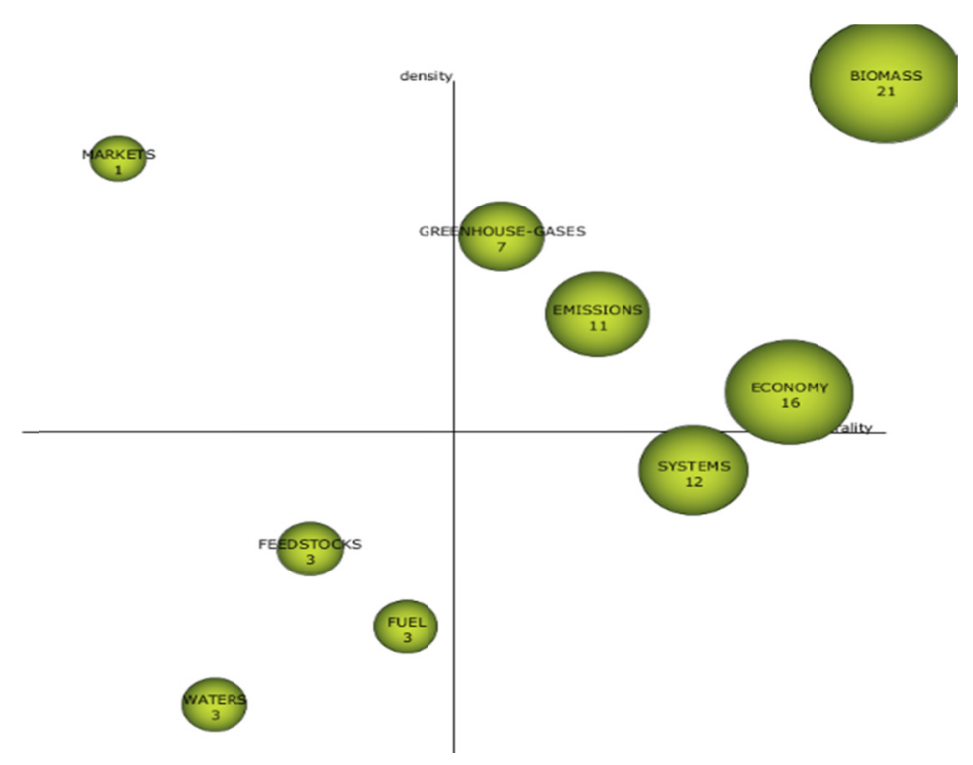

Figure 11. Strategic map (2013-2018) constructed using SciMat

Table 5. Strategic map topics (2013 to 2018)

\begin{tabular}{lllll}
\hline Topics & Documents & h-index & Centrality & Density \\
\hline Biomass & 163 & 21 & 126.75 & 78.95 \\
Greenhouse-gases & 19 & 7 & 37.94 & 20.77 \\
Economy & 66 & 16 & 76.65 & 10.51 \\
Emissions & 24 & 11 & 46.22 & 10.82 \\
Systems & 43 & 12 & 63.02 & 8.95 \\
Waters & 3 & 3 & 16.03 & 3.12 \\
Feedstocks & 4 & 3 & 21.57 & 3.39 \\
Fuel & 8 & 3 & 32.85 & 3.2 \\
Markets & 1 & 1 & 1.85 & 25 \\
\hline
\end{tabular}

Sixteen of the twenty most cited articles in the area of interest of the present research were published in the range of 2007 to 2012, with high h-index values. This reflects the growth of publications in the period from 2013 to 2018. The most cited studies are directly related to the study of the biomass-to-energy supply chain. They indicate the importance and concern of the academy in responding bottlenecks that hinder the exploration of alternative sources for energy generation, such as the issue related to the supply chain management.

At the end of the analysis, it was found that the most developed and, consequently, the most important theme for the construction and extension of this scientific field is "biomass", accompanied by "bioenergy", "supply chain management" and "optimization", which have strong centrality and density. By analysing the network of themes, it was possible to verify that research in the area of biomass supply chain management for energy generation is focused on the chain's ability to self-supply the inputs needed for energy production, as can be illustrated in the map in Figure 12. 


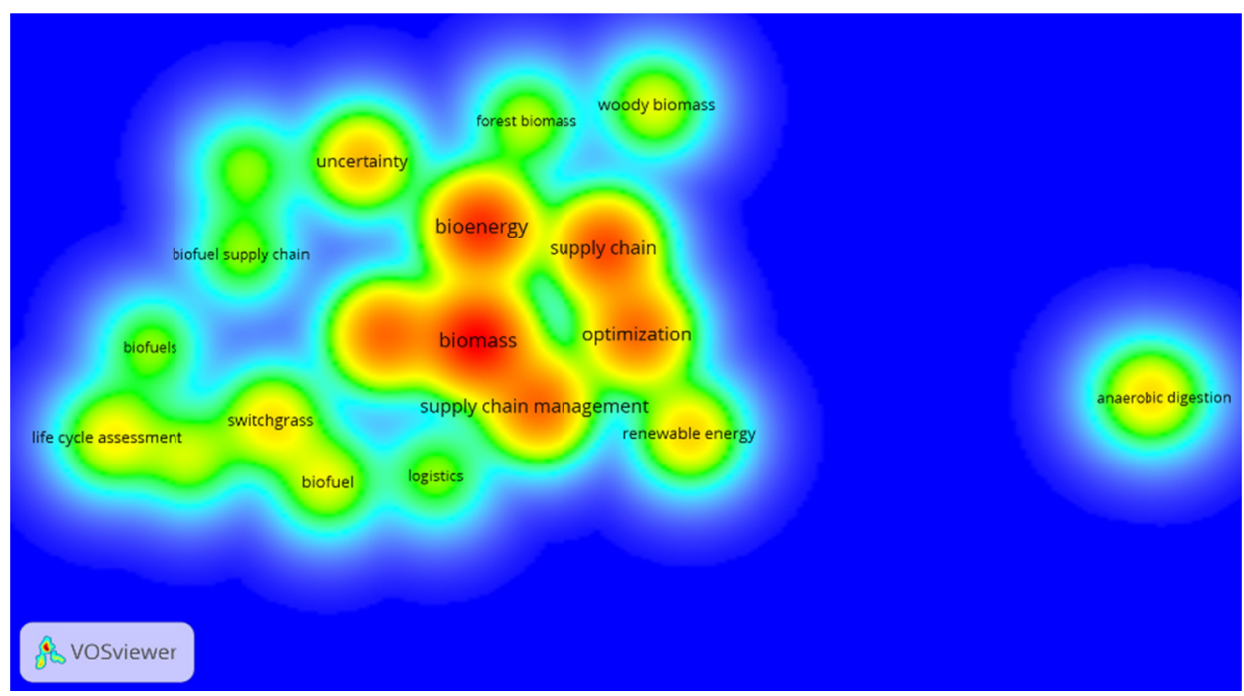

Figure 12. Keywords: Strategic map using the VOSviewer software

In addition to the concern for the uninterrupted supply of biomass, supply chain studies also addressed issues related to the environment and sustainability, especially in the last period analysed (2013-2018). In relation to these themes, Gonzazes et al. (2015), Hansson and Hackel (2016), and Inghels, Dullaert, and Bloemhof (2016) studied models of sustainability criteria for solid biomass, reverse logistics and a systematic approach to chain sustainable supply under quality uncertainty, respectively.

Although cross-sectional topics such as Economy and Waters were also addressed, both in second and third studied intervals. Ghaffariyan, Brown, Acuna and McGrath (2016) focused on investigating the economic costs involved in logistic processes and Chugh et al. (2016) conducted an economic analysis of the supply chain for alternative biomass. In addition, Elia, Baliban, and Floudas (2012), and Eranki et al. (2013) discussed concerns about efficient water consumption.

\subsection{Main Research Trends}

In the first period analysed, from 2000 to 2006 , the studies were mostly concerned with the use of soil and raw materials (types of biomass) for energy production. However, it was possible to identify some emerging future trends, starting from the connections of the focal themes, e.g., 'renewable energy' to themes such as 'economy', which in the period from 2007 to 2012 became an important theme. Although, from 2013 onward, these themes lost much of their attention (Figure 10). Moreover, in the period 2000-2006, the main themes identified were crops for energy production (two articles), and the development of indicators to optimize resource management, such as transport routes and storage of agricultural crops for biofuel production. The economic dimension and the sustainability aspects related to the transition from the fossil economy to the green economy, more specifically in the Triple Bottom Line (TBL) approach (economic, environmental and social aspects), started to gain attention (Van Dam et al., 2005).

In the second period, i.e., 2007 to 2012, 35 publications were found to discuss biomass-to-energy SCM. During this period, the term "Supply-chain" was consolidated, becoming a focal theme, as well as "Land-use changes" and "Resources". This can influence the development of studies of industrial ecology, industrial symbiosis and discussions around the measurement of sustainable development. It is interesting to highlight the appearance of peripheral themes (which did not occur in the previous period). This fact is important because the peripheral themes are internally well developed, but still isolated from other themes. Most of the studies in this period of analysis were related to the study of supply chain management for power generation, addressing, in particular, mathematical modeling of the supply chain (16 publications), technological aspects of energy conversion (12 publications) and availability of biomass (7 publications).

The economic aspects became a topic of interest being allocated as a basic theme and having as its main interests the terms: "environmental" (Cucek, Klemes, \& Kravanja, 2012); "systems", related to chain management systems (Perez-Fortes, Lainez-Aguirre, Arranz-Piera, Velo, \& Puigjaner, 2012); and "emissions" (Meyer \& Mina, 2012; Routa, Kellomaki, Kilspelainen, Peltola, \& Strandman, 2011). The economic issue, which at the 
beginning (2000 to 2006) did not held density or centrality in studies related to Supply Chain Management for energy generation, was consolidated as a focal theme from 2013.

In the last period analysed (2013 to October 2018), the focal themes detected were "Biomass", "Economy", "Emissions" and "Greenhouse gases". It is observed that the concerns are related to new inputs for energy production, such as forests (Bruckman et al., 2018; Simoes, Dinardi, \& da Silva, 2018; Vacchiano et al., 2018). Although, in the period from 2007 to 2012, the forest residue had already occupied a prominent position among the publications. Only in this scope were nine publications, mainly associated to optimization research and mathematical modeling (Alam, Pulkki, Shahi, \& Upadhyay, 2012; Kuhmaier \& Stempfer, 2012).

Factors inherent to the definition of sustainability, i.e., the combination of economic, social and environmental aspects, were also highlighted in this last period (14 publications), with emphasis on articles dealing with the development and management of energy forests. Furthermore, most of the time, they are associated with optimization research and mathematical modeling, especially in European countries (England and Italy) and the United States and Canada.

Regarding the economic aspects, the use and productivity of the land (Tonini, Albizzati, \& Astrup, 2018; Zhong et al., 2018), life cycle (Thakrar, Goodkind, Tessum, Marshall, \& Hill, 2018) and energy efficiency (Garofalo, Campi, Vonella, \& Mastrorilli, 2018) were explored. The environmental issue that was discussed by Ahmed and Sarkar (2018) and by Hansson and Hackl (2016) addresses aspects related to emission reduction and environmental conservation.

Ahmed and Sarkar (2018) present the advantages of supply chain management for the production of second-generation biofuels by reducing the amount of $\mathrm{CO}_{2}$ emission. Related to this theme, Bergendahl, Sarkis, and Timko (2018) carried out a research that can open a new field of study of Supply Chain Management, inserting elements such as water use management in the process.

Thus, according to the observed orientation of the publications analysed from 2000 to October 2018, some themes have been present since the beginning of the analysis. Studies on optimization and mathematical modeling, either biorefinery localization or input mapping for energy conversion, dominated the sample being present since its beginning, totalizing 49 articles or $22 \%$ of the publications, of which 23 were related to the use of energy forests.

The issue related to the analysis of GHG emissions has also been discussed since 2007. Until October 2018, 36 publications were devoted to the term (16\%), which sought to study ways to reduce GHG emissions not only in the biofuel production process, but also throughout the supply chain, in order to make it environmentally and economically more sustainable. However, given that, there is still a lack of more multidimensional evaluation studies of the supply chain, there is a strong tendency to develop new studies and future publications on this topic, associating it with several issues such as environment, waste resources, emissions and management systems.

Thus, it is important to highlight that the key words selected: Biomass, Energy and Supply Chain Management are in line with the researched literature. Despite the diversity of the words, they have managed to bring together a range of scientific fields important for the development of science related to biomass, energy production and SCM. The research, therefore, by means of the chosen terms expands previous works that discuss the same subject, as for example, Seuring and Miller (2008), that they review literature on supply chain and the dimensions of the sustainable development, providing specific tendencies to the bioenergy sector.

The research also contributes in the methodological sense to works such as Gold and Seuring (2011), which through a literature review analyzed articles on bioenergy and supply chain management, concluding that the most important terms related to this theme are linked to aspects such as harvesting, collection, storage and transportation. This research, which used software algorithms to generate trends, showed that besides these issues, economic attributes, life cycle and land use, also concentrate a large part of the debate on the SCM.

For the moment, it is important to note that the trends identified do not occur in isolation. As demonstrated at the beginning of the study, the terms discussed here are transdisciplinary and cover several areas of research. There were also publications that dealt with several aspects at the same time, contributing to the engagement, training and extension of the study of the supply chain management of biomass for energy generation.

\section{Final Considerations}

The analysis demonstrated that biomass-to-energy SCM is a topic that has gained increased attention over the last six years. In spite of the fact that most research on energy generation from alternative sources focuses primarily on fuel production, engineering and biotechnology, there are groups of researchers, mainly in the 
United States, England and Italy that are focusing on exploring and assessing ways for making biomass-to-energy SCM to emerge as a promising option for contributing to the global energy matrix in the future.

The bibliometric analysis shows that the biomass-to-energy SCM is a global topic of concern. Countries (such as Brazil, India, Russia and China), which theoretically would have the greatest interest because of their availability of energy resources and continental dimensions, as well as greater difficulties in managing supply chains, have not shown an increasing interest yet (at least from a scientific research perspective. The multi-level stakeholders involved in the biomass-to-energy SCM will require evidence on the need of new approaches in this field, especially as reliance on fossil fuels will need to be reduced in the future. This evidence will need to be focused on the ability of these countries to ensure a constant supply of biomass for energy generation and to develop an economy of scale that will control and maintain the continuous production of bioenergy.

Consequently, future research should focus on identifying key strategic areas of research within the biomass-to-energy supply chain management where there are emerging issues of concern, such as sustainability, technology innovation, storage and heat conservation can set the pace for transformational change. Thus, gains in efficiency, competitiveness and compliance with environmental standards would contribute to the consolidation of the biomass energy sector in the global energy matrix.

\section{Acknowledgements}

The authors thank the Coordination of Improvement of Higher Education Personnel (Coordenação de Aperfeiçoamento de Pessoal de Nível Superior-CAPES) for the financial support of the research project, making possible the production of this study.

\section{References}

Ahmed, W., \& Sarkar, B. (2018). Impact of carbon emissions in a sustainable supply chain management for a second generation biofuel. Journal of Cleaner Production, 186(6), 807-820. https://doi.org/10.1016/ j.jclepro.2018.02.289

Alam, M. B., Pulkki, R., Shahi, C., \& Upadhyay, T. (2012). Modeling Woody Biomass Procurement for Bioenergy Production at the Atikokan Generating Station in Northwestern Ontario, Canada. Energies, 5(12), 5065-5085. https://doi.org/10.3390/en5125065

Albert-Moran, G., \& Soriano, D. R. (2016). A bibliometgric analysis of international impact of business incubators. Journal of Business Research, 69(5), 1775-1779. https://doi.org/10.1016/j.jbusres.2015.10.054

Ayoub, N., Martins, R., Wang, K. F., Seki, H., \& Naka, Y. (2007). Two levels decision system for efficient planning and implementation of bioenergy production. Energy Conversion \& Management, 48(3), 709-723. https://doi.org/10.1016/j.enconman.2006.09.012

Balaman, S. Y., \& Selim, H. (2014). A linear multiobjective fuzzy anaerobic digestion based management model bioenergy supply chains. Energy, 74(9), 928-940. https://doi.org/10.1016/j.energy.2014.07.073

Benedek, J., Tihamer-Tibor, S., \& Bartók, B. (2018). Evaluation of renewable energy sources in peripheral áreas and renewable energy-based rural development. Renewable \& Sustainable Energy Reviews, 90(7), 516-535. https://doi.org/10.1016/j.rser.2018.03.020

Bergendahl, J. A., Sarkis, J., \& Timko, M. T. (2018). Transdisciplinarity and the food energy and water nexus: Ecological modernization and supply chain sustainability perspectives. Resources, Conservation \& Recycling, 133(6), 309-319. https://doi.org/10.1016/j.resconrec.2018.01.001

Bruckman, V. J., Haruthaithanasan, M., Miller, R. O., Terada, T., Brenner, A. K., Kraxner, F., \& Flaspohler, D. (2018). Sustainable Forest Bioenergy Development Strategies in Indochina: Collaborative Effort to Establish Regional Policies. Forests, 9(4), 1 20. https://doi.org/10.3390/f9040223

Carleton, L. E., \& Becker, D. (2018). Forest Biomass Policy in Minnesota: Supply Chain Perspectives on Barriers to Bioenergy Development. Forests, 9(5), 1-13. https://doi.org/10.3390/f9050254

Castillo-Vergara, M., Alvarez-Marin, A., \& Placencio-Hidalgo, D. (2018). A bibliometric analysis of creativity in the field of business economics. Journal of Business Research, 85(4), 1-9. https://doi.org/10.1016/ j.jbusres.2017.12.011

Chen, C.-W., \& Fan, Y. (2012). Bioethanol supply chain system planning under supply and demand uncertainties. Transportation Research Part E: Logistics and Transportation Review, 48(1), 150-164. https://doi.org/10.1016/j.tre.2011.08.004 
Chen, G., \& Xiao, L. (2016). Selecting publication keywords for domain analysis in bibliometrics: A comparasion of three methods. Journal of Informetrics, 10(1), 212-223. https://doi.org/10.1016/ j.joi.2016.01.006

Cherubini, F., \& Jungmeier, G. (2010). LCA of a biorefinery concept producing bioethanol, bioenergy, and chemicals from switchgrass. The International Journal of Life Cycle Assessment, 15(1), 53-66. https://doi.org/10.1007/s11367-009-0124-2

Chugh, S., Yu, T. E., Jackson, S. W., Larson, J. A., English, B. C., \& Cho, S.-H. (2016). Economic analysis of alternative logistics systems for Tennessee-produced switchgrass to penetrate energy markets. Biomass \& Bioenergy, 85(2), 25-34. https://doi.org/10.1016/j.biombioe.2015.11.017

Cobo, M. J., López-Herrera, A. G., Herrera-Viedma, E., \& Herrera, F. (2011). Science mapping software tools: Review, analysis, and cooperative study among tools. Journal of the Association for Information Science \& Technology, 62(7), 1382-1402. https://doi.org/10.1002/asi.21525

Cobo, M. J., López-Herrera, A. G., Herrera-Viedma, E., \& Herrera, F. (2012). SciMAT: A new science mapping analysis software tool. Journal of the Association for Information Science \& Technology, 63(8), 1609-1630. https://doi.org/10.1002/asi.22688

Comission of the European Communities. (2008). Communication from the Commission to the European Parliament, the Council, the European Economic and Social Committee and the Committee of the Regions. 2020 by 2020, Europe's climate change opportunity, COM(2008) 30 final. Retrieved December 1, 2018, from https://eur-lex.europa.eu/LexUriServ/LexUriServ.do?uri=COM:2008:0030:FIN:EN:PDF

Comission of the European Communities. (2008). Directive 2009/28/EC of the European Parliament and of the Council of 23 April 2009 on the promotion of the use of energy from eenewable sources and amending and subsequently repealing Directives 2001/77/EC and 2003/30/EC. Retrieved December 1, 2018, from https://eur-lex.europa.eu/legal-content/EN/ALL/?uri=celex\%3A32009L0028

Corcelli, F., Fiorentino, G., Vehmas, J., \& Ulgiati, S. (2018). Energy efficiency and environmental assessment of papermaking from chemical pulp-A Finland case study. Journal of Cleaner Production, 198(10), 96-111. https://doi.org/10.1016/j.jclepro.2018.07.018

Cucek, L., Klemes, J. J., \& Kravanja, Z. (2012). Carbon and nitrogen trade-offs in biomass energy production. Clean Technologies \& Environmental Policy, 14(3), 389-397. https://doi.org/10.1007/s10098-012-0468-3

Dae-Hyun, J., Cho, K., Park, S., \& Hong, S.-K. (2016). Effects of knowledge diffusion on international joint research and science convergence: Multiple case studies in the fields of lithium-ion battery, fuel cell and wind power. Technological Forecasting \& Social Change, 108(7), 15-27. https://doi.org/10.1016/ j.techfore.2016.03.017

Dragoni, F., Di Nasso, N. N., Tozzini, C., Bonari, E., \& Ragaglini, G. (2015). Aboveground Yield and Biomass Quality of Giant Reed (Arundo donax L.) as Affected by Harvest Time and Frequency. BioEnergy Research, 8(3), 1321-1331. https://doi.org/10.1007/s12155-015-9598-x

Eksioglu, S. D., Acharya, A., Leightley, L. E., \& Arora, S. (2009). Analyzing the design and management of biomass-to-biorefinery supply chain. Computers \& Industrial Engineering, 57(4), 1342-1352. https://doi.org/10.1016/j.cie.2009.07.003

Elghali, L., Clift, R., Sinclair, P., Panoutsou, C., \& Bauen, A. (2007). Developing a sustainability framework for the assessment of bioenergy systems. Energy Policy, 35(12), 6075-6083. https://doi.org/10.1016/ j.enpol.2007.08.036

Elia, J. A., Baliban, R. C., \& Floudas, C. A. (2012). Nationwide energy supply chain analysis for hybrid feedstock processes with significant $\mathrm{CO}_{2}$ emissions reduction. AIChE Journal, 58(7), 2142-2154. https://doi.org/10.1002/aic.13842

Ellegaard, O., \& Wallin, J. A. (2015). The bibliometric analysis of scholarly production: How great is the impact? Scientometrics, 105(3), 1809-1831. https://10.1007/s11192-015-1645-z

Eranki, P. L., Manowitz, D. H., Bals, B. D., Izaurralde, R. C., Kim, S., \& Dale, B. E. (2013). The watershed-scale optimized and rearranged landscape design (WORLD) model and local biomass processing depots for sustainable biofuel production: Integrated life cycle assessments. Biofuels Bioproducts \& Biorefining-Biofpr, 7(5), 537-550. https://doi.org/10.1002/bbb.1426 
Garofalo, P., Campi, P., Vonella, A. V., \& Mastrorilli, M. (2018). Application of multi-metric analysis for the evaluation of energy performance and energy use efficiency of sweet sorghum in the bioethanol supply chain: A fuzzy-based expert system approach. Applied Energy, 220(6), 313-324. https://doi.org/ 10.1016/j.apenergy.2018.03.065

Gautam, P. (2017). An overview of the Web of Science record of scientific publications (2004-2013) from Nepal: focus on disciplinary diversity and international collaboration. Scientonometrics, 113(3), 1245-1267. https://doi.org/10.1007/s11192-017-2538-0

Gebresenbet, G., Bosona, T., Olsson, S.-O., \& García-Galindo, D. (2018). Smart System for the Optimization of Logistics Performance of the Pruning Biomass Value Chain. Applied Sciences-Basel, 8(7), 1-17. https://doi.org/10.3390/app8101987

Ghaffariyan, M. R., Brown, M., Acuna, M., \& McGrath, J. (2016). Optimized Harvesting Cost for Mallee Supply chain in Western Australia. Croation Journal of Forest Engineering, 37(1), 17-25.

Gigler, J. K., Hendrix, E. M. T., Heesen, R. A., van den Hazelkamp, V. G. W., \& Meerdink, G. (2002). On optimisation of agri chains by dynamic programming. European Journal of Operational Research, 139(3), 613-625. https://doi.org/10.1016/S0377-2217(01)00191-6

Gold, S., \& Seuring, S. (2011). Supply chain and logistics issues of bio-energy production. Journal of Cleaner Production, 19(1), 32-42. https://doi.org/10.1016/j.jclepro.2010.08.009

Gonzalez, E. D. R. S., Sarkis, J., Huisingh, D., Huatuco, L. H., Maculan, N., Montoya-Torres, J. R., \& de Almeida, C. M. V. B. (2015). Making real progress toward more sustainable societies using decision support models and tools: Introduction to the special volume. Journal of Cleaner Production, 105(10), 1-13. https://doi.org/10.1016/j.jclepro.2015.05.047

Handfield, R., Soufre, R., \& Walton, S. (2005). Integrating environmental management and supply chain strategies. Business Strategy and the Environment, 14(1), 1-19. https://doi.org/10.1002/bse.422

Hassini, E., Surti, C., \& Searcy, C. (2012). A literature review and a case study of sustainable supply chains with a focus on metrics. International Journal of Production Economics, 140(1), 69-82. https://doi.org/10.1016/ j.ijpe.2012.01.042

Hansson, J., \& Hackl, R. (2016). The potential influence of sustainability on the European Union pellets marketthe example of Sweden. Wiley Interdisciplinary Reviews: Energy and Environment, 5(4), 413-429. https://doi.org/10.1002/wene.199

Higuita, L. C., Awad, G., \& Cardona, C. J. F. (2012). Análisis bibliométrico del campo modelado de diffusion de innovaciones. Estudios Gerenciales, 28(SP), 213-236. https://doi.org/10.18046/j.estger.2012.1486

Iakovou, E., Karagiannidis, A., Vlachos, D., Toka, A., \& Malamakis, A. (2010). Waste biomass-to-energy supply chain management: A critical synthesis. Waste Management, 30(10), 1860-1870. https://doi.org/ 10.1016/j.wasman.2010.02.030

Iacovidou, E., Hahladakis, J., Deans, I., Velis, C., \& Purnell, P. (2017). Technical properties of biomass and solid recovered fuel (SRF) co-fired with coal: Impact of multi-dimensional resource recovery value. Waste Managemant, 73(3), 535-545. https://doi.org/10.1016/j.wasman.2017.07.001

Inghels, D., Dullaert, W., \& Bloemhof, J. (2016). A model for improving sustainable green waste recovery. Resources, Conservation \& Recycling, 110(7), 61-73. https://doi.org/10.1016/j.resconrec.2016.03.013

IEA (International Energy Agency). (2017). Key World Energy Statistics. France: Chirat. https://doi.org/10.1787/ world_energy_stats-2017-en

Jansen, P., \& Kuiper, L. (2004). Double green energy from traditional coppice stands in the Netherlands. Biomass \& Bioenergy, 26(4), 401-402. https://doi.org/10.1016/j.biombioe.2003.08.004

Jeong, J. S., \& Ramírez-Gómez, A. (2018). Optimizing the location of a biomass plant with a fuzzy-DEcision-MAking Trial and Evaluation Laboratory (F-DEMATEL) and multi-criteria spatial decision assessment for renewable energy management and long-term sustainability. Journal of Cleaner Production, 182(5), 509-520. https://doi.org/10.1016/j.jclepro.2017.12.072

Kim, S., Kim, S., \& Kiniry, J. R. (2018). Two-phase simulation-based location-allocation optimization of biomass storage distribution. Simulation Modeling Practice \& Theory, 86(8), 155-168. https://doi.org/ 10.1016/j.simpat.2018.05.006 
Kuhmaier, M., \& Stampfer, K. (2012). Development of a Multi-Criteria Decision Support Tool for Energy Wood Supply Management. Croatian Journal of Forest Engineering, 33(2), 181-198.

Lam, H. L., Varbanov, P., \& Klemes, J. J. (2010). Minimising carbon footprint of regional biomass supply chains. Resources, Conservation \& Recycling, 54(5), 303-309. https://doi.org/10.1016/j.resconrec.2009. 03.009

Lam, H. L., Varbanov, P. S., \& Klemes, J. J. (2011). Regional renewable energy and resource planning. Applied Energy, 88(2), 545-550. https://doi.org/10.1016/j.apenergy.2010.05.019

Lewandowski, I., Clifton-Brown, J. C., Scurlock, J. M. O., \& Huisman, W. (2000). Miscanthus: European experience with a novel energy crop. Biomass \& Bioenergy, 19(4), 209-227. https://doi.org/10.1016/ S0961-9534(00)00032-5

Mafakheri, F., \& Nasiri, F. (2014). Modeling of biomass-to-energy supply chain operations: Applications, challenges and research directions. Energy Policy, 67(4), 16-126. https://doi.org/10.1016/j.enpol. 2013.11.071

Mayring, P. (2003). Qualitative Content Analysis. Weinheim, Germany: Beltz Verlag.

Meyer, N. K., \& Mina, M. (2012). Wood energy fuel cycle optimization in beech and spruce forests. Environmental Research Letters, 7(1), 1-9. https://doi.org/10.1088/1748-9326/7/1/014001

Miguéis, A., Neves, B., Silva, A. L., Trindade, A., \& Bernardes, J. A. (2013). A importância das palavras-chave dos artigos científicos da área das Ciências Farmacêuticas, depositados no Estudo Geral: estudo comparativo com os termos atribuídos na MEDLINE. InCID: Revista de Ciência da Informação \& Documentação, 4(2), 112-125. https://doi.org/10.11606/issn.2178-2075.v4i2p112-125

Montero-Diaz, J., Cobo, M. J., Gutiérrez-Salcedo, M., Segado-Boj, F., \& Herrera-Viedma, E. (2018). Mapeo científico de la Categoría Comunicación en WoS (1980-2013). Revista Científica de Educomunicación, 26(55), 81-91. https://doi.org/10.3916/C55-2018-08

Olsson, O., Eriksson, A., Sjostrom, J., \& Anerud, E. (2016). Keep that fire burning: Fuel supply risk management strategies of Swedish district heating plants and implications for energy security. Biomass \& Bionergy, 90(7), 70-77. https://doi.org/10.1016/j.biombioe.2016.03.015

Perera, F. (2017). Pollution from Fóssil-Fuel Combustion is the Leading Environmental Threat to Global Pediatric Health and Equity: Solutions Exist. International Journal of Environmental Reaearch and Public Health, 15(1), 1-17. https://doi.org/10.3390/ijerph15010016

Perez-Fortes, M., Lainez-Aguirre, J. M., Arranz-Piera, P., Velo, E., \& Puigjaner, L. (2012). Design of regional and sustainable bio-based networks for electricity generation using a multi-objective MILP approach. Energy, 44(1), 79-95. https://doi.org/10.1016/j.energy.2012.01.033

Roder, M., Whittaker, C., \& Thornley, P. (2015). How certain are greenhouse gas reductions from bioenergy? Life cycle assessment and uncertainty analysis of wood pellet-to-electricity supply chains from forest residues. Biomass \& Bioenergy, 79(8), 50-63. https://doi.org/10.1016/j.biombioe.2015.03.030

Routa, J., Kellomaki, S., Kilpelainen, A., Peltola, H., \& Strandman, H. (2011). Effects of forest management on the carbon dioxide emissions of wood energy in integrated production of timber and energy biomass. Global Change Biology Bioenergy, 3(6), 483-497. https://doi.org/10.1111/j.17571707.2011.01106.x

Salimi, F., \& Vandani, B. (2018). Designing a bio-fuel network reliability and risk-pooling effect in bio-refineries. Reliability Engineering \& System Safety, 174(6), 96-107. https://doi.org/10.1016/j.ress.2018. 02.020

Schreiber, M. (2015). Restricting the h-index to a publication and citation time window: A case study of a timed Hirsch index. Journal of Informetrics, 9(1), 150-155. https://doi.org/10.1016/j.joi.2014.12.005

Seuring, S., \& Müller, M. (2008). From a literature review to a conceptual framework for sustainable supply chain management. Journal of Cleaner Production, 16(5), 1699-1710. https://doi.org/10.1016/j.jclepro. 2008.04.020

Shabani, N., \& Sowlati, T. (2013). A mixed integer non-linear programming model for tactical value chain optimization of a wood biomass power plant. Applied Energy, 104(4), 353-361. https://doi.org/ 10.1016/j.apenergy.2012.11.013 
Simoes, D., Dinardi, A. J., \& da Silva, M. R. (2018). Investment Uncertainty Analysis in Eucalyptus Bole Biomass Production in Brazil. Forests, 9(7), 1-13. https://doi.org/10.3390/f9070384

Skoulou, V., \& Zabaniotou, A. (2007). Investigation of agricultural and animal wastes in Greece and their allocation to potential application for energy production. Renewable \& Suatainable Energy Reviews, 11(8), 1698-1719. https://doi.org/10.1016/j.rser.2005.12.011

Sokhansanj, S., Mani, S., Turhollow, A., Kumar, A., Bransby, D., Lynd, L., \& Laser, M. (2009). Large-scale production, harvest and logistics of switchgrass (Panicum virgatum L.)-current technology and envisioning a mature technology. Biofuels, Bioproducts \& Biorefining-Biofpr, 3(2), 124-141. https://doi.org/10.1002/ bbb. 129

Steeves, B. B., \& Ouriques, H. R. (2016). Energy Security: China and the United States and the Divergence in Renewable Energy. Contexto Internacional, 38(2), 643-662.

Stupak, I., Lattimore, B., Titus, B. D., \& Smith, C. T. (2011). Criteria and indicators for sustainable forest fuel production and harvesting: A review of current standards for sustainable forest management. Biomass \& Bioenergy, 35(8), 3287-3308. https://doi.org/10.1016/j.biombioe.2010.11.032

Svanberg, M., Finnsgard, C., Floden, J., \& Lundgren, J. (2018). Analyzing animal waste-to-energy supply chains: The case of horse manure. Renewable Energy, 129(12-Part B), 830-837. https://doi.org/10.1016/ j.renene.2017.04.002

Thakrar, S. K., Goodkind, A. L., Tessum, C. W., Marshall, J. D., \& Hill, J. D. (2018). Life cycle air quality impacts on human health from potential switchgrass production in the United States. Biomass \& Bioenergy, 114(7), 73-82. https://doi.org/10.1016/j.biombioe.2017.10.031

Tonini, D., Albizzati, P. F., \& Astrup, T. F. (2018). Environmental impacts of food waste: Learnings and challenges from a case study on UK. Waste Management, 76(6), 744-766. https://doi.org/10.1016/ j.wasman.2018.03.032

Union of Concerned Scientists. (2016). The Hidden Costs of Fossil Fuels. Retrieved December 1, 2018, from https:/www.ucsusa.org/clean-energy/coal-and-other-fossil-fuels/hidden-cost-of-fossils\#.XFCfjVxKjIW

Vacchiano, G., Berreti, R., Motta, R., \& Mondino, E. B. (2018). Assessing the availability of forest biomass for bioenergy by publicly available satellite imagery. iForest-Biogeosciences \& Forestry, 11(4), 459-468. https://doi.org/10.1016/j.foreco.2017.11.047

Van Dam, J. E. G., de Klerk-Engels, B., Struik, P. C, \& Rabbinge, R. (2005). Securing renewable resource supplies for changing market demands in a bio-based economy. Industrial Crops \& Products, 21(1), 129-144. https://doi.org/10.1016/j.indcrop.2004.02.003

Van Eck, N. J., Waltman, L., Dekker, R., \& van den Berg, J. (2010). A comparison of two techniques for bibliometric mapping: Multidimensional scaling and VOS. Journal of the American Society for Information Science and Technology, 61(12), 2405-2416. https://doi.org/10.1002/asi.21421

Vyhmeister, E., Ruiz-Mercado, G. J., Torres, A. I. \& Posada, J. A. (2018). Optimization of multi-pathway production chains and multi-criteria decision-making through sustainability evaluation: A biojet fuel production case study. Clean Technologies and Environmental Policy, 20(7), 1697-1719. https://doi.org/ 10.1007/s10098-018-1576-5

Waltman, L., \& van Eck, N. J. (2012). A new methodology for constructing a publication-level classification system of science. Journal of the American Society for Information Science and Technology, 63(12), 2378-2392. https://doi.org/10.1002/asi.22748

World Health Organization. (2018). Ambient air pollution: Health impacts. Retrieved December 1, 2018, from https://www.who.int/airpollution/ambient/health-impacts/en/

Zamboni, A., Shah, N., \& Bezzo, F. (2009). Spatially Explicit Static Model for the Strategic Design of Future Bioethanol Production Systems. 1. Cost Minimization. Energy \& Fuels, 23(10), 5121-5133. https://doi.org/ $10.1021 / \mathrm{ef} 900456 \mathrm{w}$

Zhang, F. L., Johnson, D. M., \& Johnson, M. A. (2012). Development of a simulation model of biomass supply chain for biofuel production. Renewable Energy, 44(8), 380-391. https://doi.org/10.1016/j.renene. 2012.02.006 
Zhang, J., Osmani, A., Awudu, I., \& Gonela, V. (2013). An integrated optimization model for switchgrass-based bioethanol supply chain. Applied Energy, 102(2), 1205-1217. https://doi.org/10.1016/j.apenergy. 2012.06.054

Zhang, W., Yang, J., Sheng, P., Li, X., \& Whang, X. (2014). Potential cooperation in renewable energy between China and United States of America. Energy Policy, 75(12), 403-409. https://doi.org/10.1016/j.enpol. 2014.09.016

Zhong, J., Yu, T. E., Clark, C. D., English, B. C., Larson, J. A., \& Cheng, C.-L. (2018). Effect of land use change for bioenergy production on feedstock cost and water quality. Applied Energy, 210(1), 580-590. https://doi.org/10.1016/j.apenergy.2017.09.070

\section{Notes}

Note 1 . The same article can be allocated in more than one area.

\section{Copyrights}

Copyright for this article is retained by the author(s), with first publication rights granted to the journal.

This is an open-access article distributed under the terms and conditions of the Creative Commons Attribution license (http://creativecommons.org/licenses/by/4.0/). 